\title{
Effect of Organic Manures and Liquid Formulations on Growth, Yield and Quality of Okra [Abelmoschus esculentus (L.) Moench] cv. Arka Anamika
}

\author{
Priyanka Devanda $^{1}$, S. S. Lakhawat ${ }^{1}$, S. Pilania ${ }^{1}$, S. K. Sharma ${ }^{2}$, Azad Mordia ${ }^{3}$, \\ D. P. S. Dudi ${ }^{4}$, Sharvan Kumar Yadav ${ }^{2}$ and Pratishtha Diwaker ${ }^{1}$
}

${ }^{1}$ Department of Horticulture, ${ }^{2}$ Department of Agronomy, ${ }^{3}$ Department of Agricultural Statistics, ${ }^{4}$ Department of Soil Science and Agricultural Chemistry, Rajasthan College of Agriculture, MPUAT, Udaipur-313001, India

*Corresponding author

\section{A B S T R A C T}

The present experimentation entitled Effect of organic manures and liquid formulations on growth, yield and quality of okra (Abelmoschus esculentus L. Moench) cv. Arka Anamika was conducted at Horticulture farm, Horticulture

Keywords

Organic manures, liquid formulations, okra, split plot design

Article Info

Accepted:

12 May 2021

Available Online:

10 June 2021 Department, Rajasthan College of Agriculture, MPUAT, Udaipur during zaid season of the year 2018-2019. Results showed that the application of $\mathrm{M}_{3}$ treatment (i.e. FYM $1 / 3^{\text {rd }}+$ PROM $1 / 3^{\text {rd }}+\mathrm{NC} 1 / 3^{\text {rd }}$ equivalent to $100 \% \mathrm{RDN}$ ) as organic manures and $\mathrm{L}_{1}$ treatment (i.e. panchagavya spray @ 3\% at flowering and 15 days after flowering) as liquid formulation were recorded significantly highest values of different characters of okra such as days to first picking, fruit length $(\mathrm{cm})$, fruit weight $(\mathrm{g})$, yield per hectare $(\mathrm{q})$, net returns, fiber content $(\%)$ and also enhances soil properties. Among the treatment combinations, $\mathrm{M}_{3} \mathrm{~L}_{1}$ treatment (i.e. FYM $1 / 3^{\text {rd }}$ + PROM $1 / 3^{\text {rd }}+$ neem cake (NC) $1 / 3^{\text {rd }}$ equivalent to $100 \%$ RDN along with foliar spray of panchagavya @ 3\% at flowering and 15 days after flowering) was observed with highest fruit length $(\mathrm{cm})$, fruit weight $(\mathrm{g})$, yield per hectare $(\mathrm{q})$, and net returns (Rs. /ha) during investigation. It was also reported that soil properties and total microbial population were improved by this treatment combination.

\section{Introduction}

Okra [Abelmoschus esculentus (L.) Moench] usually known as Bhindi or lady's finger belongs to the Malvaceae family, has a chromosome number of $2 \mathrm{n}=130$. It is supposed to originate from Ethiopia. It is an annual crop of vegetables in tropical and subtropical parts of the world. In India, it is one of the most important nutritious vegetable 
crops grown round the year. Its fruits are appreciated primarily for its curry, soup of its edible young leaves is also admired. It finds use, to a small degree in dehydrated, canned or frozen forms for military off-season use at high altitudes and for export (Sharma et al., 2015).

The green pods (per $100 \mathrm{~g}$ edible portion) of okra contain $89.6 \mathrm{~g}$ moisture, $6.4 \mathrm{~g}$ carbohydrates, $0.2 \mathrm{~g}$ fat, $1.9 \mathrm{~g}$ protein, $66 \mathrm{~g}$ calcium, $56 \mathrm{mg}$ phosphorus, $43 \mathrm{mg}$ magnesium, $103 \mathrm{mg}$ potassium, $13 \mathrm{mg}$ vit. C and 88 IU vit. A (Bose et al., 2003). Tender fruits of okra are used in soups and gravies and contain high mucilage content. A mucilaginous preparation from the pods may be used for blood volume expansion or plasma replacement. Okra will be of great assistance against spermatorrhoea, genito-urinary disorders and chronic dysentery. In giving relief from hemorrhoids and curing ulcers, medicinal value of okra has also been reported.

Using organic manures to meet the nutrient requirements of crops would be an unavoidable activity for sustainable agriculture in the years to come, as organic manures typically enhance the soil's physical, chemical and biological properties while retaining the soil's moisture-bearing ability, resulting in improved crop production and maintaining crop quality. While, organic manures contain plant nutrients in small amounts compared with inorganic fertilizers, the existence of growth promoting principles such as hormones and enzymes make them necessary in ordered to boost soil fertility and crop productivity (Premsekhar and Rajshree, 2009). Organic manure increases cation exchange capacity, water holding capacity and soil phosphate availability besides enhancing fertilizer use efficiency and soil microbial population, reducing nitrogen losses due to slow nutrient release (Tadesse et al., 2013).
Panchagavya, the liquid organic manure, has the ability to encourage growth and provide resistance to the plant system. Panchagavya consists of five components, namely cow dung, urine, milk, curd, and ghee, and is widely used in agriculture, especially for horticultural crops. Jeevamruth promotes immense biological activity in soil and provides the nutrients for the crop stand. Mixing cow urine, cow dung, pulse flour and jaggary (gur), it is prepared and allowed to ferment for a week. The filtered extract is used for soil application, and numerous beneficial microorganisms are believed to microbiologically enrich soil. Jeevamruth is reported to have a very large population of nitrogen fixers, phosphate solubilizers and siderophore producers (Pathak and Ram, 2013). Cow urine is a unique product of dairy which have huge property such as manure, antimicrobial agent, disinfectant. It contains $95 \%$ water, $2.5 \%$ urea and remaining $2.5 \%$ contains mineral salts, hormones and enzymes. In organic farming, cow urine is used for preparation of number of growth promoter and bio-pesticides, which are effective in improving soil fertility, and management of large number of pests and diseases in varied group. The biochemical contents of the plants increased with cow urine application (Pradhan et al., 2018). The body fluid obtained from the earthworm is called vermiwash, without hurting them. It contains enzymes that are secretion which promote crop growth and yield and also help to establish resistance in crops receiving this spray; these preparations will definitely have soluble plant nutrients other than some organic acids and earthworm and microbial mucus (Shivasubramanian and Ganeshkumar, 2004). Keeping this view the present study entitled "Effect of organic manures and liquid formulations on growth, yield and quality of okra [Abelmoschus esculentus (L.) Moench] cv. Arka Anamika" is proposed for investigation. 


\section{Materials and Methods}

Field experiment was carried out at the Department of Horticulture, Rajasthan College of Agriculture, MPUAT, Udaipur to analysis the effect of organic manures and liquid formulations on growth, yield and quality of okra. The experiment was conducted in split plot design replicated thrice. There were eighteen treatment combinations involving different organic manures as soil application and liquid formulations as foliar spray along with organic manures as control. The details of used organic manures and liquid formulations were given as under:

\section{Main plot: Organic manures (M) - 03}

$\mathrm{M}_{1}$ : FYM 1/3rd + Vermicompost (VC) $1 / 3 \mathrm{rd}+$ Neem cake (NC) $1 / 3$ rd equivalent to $100 \%$ RDN

$\mathrm{M}_{2}$ : FYM 1/3rd + Enriched compost (EC) $1 / 3^{\text {rd }}+$ Vermicompost (VC) $1 / 3$ rd equivalent to $100 \% \mathrm{RDN}$

$\mathrm{M}_{3}$ : FYM $1 / 3$ rd + PROM 1/3rd + Neem cake (NC) $1 / 3$ rd equivalent to $100 \%$ RDN

Sub plot: Liquid formulations spray (L) 06

$\mathrm{L}_{1}$ : Panchagavya spray (3\%) at first flowering and 15 DAF (Days after flowering)

$\mathrm{L}_{2}$ : Jeevamrut (Spray @ 500 litre/ha) at first flowering and $15 \mathrm{DAF}$

$\mathrm{L}_{3}$ : Cow urine spray (10\%) at first flowering and $15 \mathrm{DAF}$

$\mathrm{L}_{4}$ : Vermiwash spray (10\%) at first flowering and $15 \mathrm{DAF}$

L5 $_{5}$ : Matka khad spray (10\%) at first flowering and $15 \mathrm{DAF}$
$\mathrm{L}_{6}$ : Control (water spray) at first flowering and 15 DAF.

The size of experimental plot was $1.8 \times 3 \mathrm{~m}$ and spacing i.e. $45 \times 30 \mathrm{~cm}$ was maintained. The nutrient content of organic manures used such as FYM, vermicompost, enriched compost, neem cake and PROM were 0.50, $0.24 ; 1.12,0.27 ; 1.30,0.47 ; 5.09,1.19$ and $0.42,10.42 \% \mathrm{~N}$ and $\mathrm{P}$, respectively. The organic manures used as soil application, applied into soil one week before sowing.

\section{Observations}

\section{Days to first picking}

Five randomly selected plants were tagged and the number of days taken to first harvest were counted from the date of sowing and average value was taken as days to first harvest.

\section{Fruit length (cm)}

At the peak of harvesting, length of 10 randomly selected fruits was measured in centimeters then average length per fruit was worked out for each treatment.

\section{Fruit weight (g)}

The weight of 10 fresh fruits harvested from randomly selected and tagged five plants was taken during harvesting and the average weight of fruit was calculated by mean weight of ten plants.

\section{Yield (q/ha)}

The fresh yield obtained from each plot including selected plants in each harvest was sum up which gave the total fruit yield per plot and thereafter with the use of multiplication factor this yield was converted into per hectare for each treatment. 


\section{Fiber content (\%)}

Fiber content was dictated by the method proposed by Maynard, 1970. Representative ground fruit sample of $2 \mathrm{~g}$ was refluxed with 1.25 per cent $\mathrm{H}_{2} \mathrm{SO}_{4}$ and washed then again refluxed with 1.25 per cent $\mathrm{NaOH}$ for 30 minutes, respectively. The sample was dried out, weighed and ignited in muffle furnace. Loss in weight was considered as crude fibre content and expressed on the basis of using following relationship:

Fibre content $(\%)$

$$
\begin{gathered}
\mathrm{W}_{2}-\mathrm{W}_{3} \\
=-----\mathrm{X} 100 \\
\mathrm{~W}_{1}
\end{gathered}
$$

Where,

$\mathrm{W}_{1}=$ Initial weight of sample

$\mathrm{W}_{2}=$ Weight of refluxed sample

$\mathrm{W}_{3}=$ Weight of ignited sample

\section{Results and Discussion}

\section{Days to first picking}

During investigation, it was observed that the significantly minimum number of days to first picking i.e. 47.83 and 47.00 days were found with treatment of $\mathrm{M}_{3}$ (i.e. FYM $1 / 3^{\text {rd }}+\mathrm{PROM}$ $1 / 3^{\text {rd }}+\mathrm{NC} 1 / 3^{\text {rd }}$ equivalent to $100 \%$ RDN) and $\mathrm{L}_{1}$ treatment (i.e. panchagavya @ 3\% spray), respectively while, the maximum number of days to first picking i.e. 49.37 and 50.67 days were recorded with $\mathrm{M}_{2}$ treatment (i.e. FYM $1 / 3^{\text {rd }}+\mathrm{EC} 1 / 3^{\text {rd }}+\mathrm{VC} 1 / 3^{\text {rd }}$ equivalent to $100 \%$ $\mathrm{RDN}$ ) and $\mathrm{L}_{6}$ treatment (water spray), respectively. Among treatment combinations, the treatment of $\mathrm{M}_{3} \mathrm{~L}_{1}$ (i.e. FYM $1 / 3^{\text {rd }}+$ PROM $1 / 3^{\text {rd }}+\mathrm{NC} 1 / 3^{\text {rd }}$ equivalent to $100 \%$
RDN and panchagavya @ 3\% spray) was noticed with minimum days to first harvest i.e. 45.07 days while, maximum days to first harvest i.e. 52.07 days was recorded with $\mathrm{M}_{2} \mathrm{~L}_{6}$ treatment (i.e. FYM $1 / 3^{\text {rd }}+\mathrm{EC} 1 / 3^{\text {rd }}+$ VC $1 / 3^{\text {rd }}$ equivalent to $100 \% \mathrm{RDN}$ and Water spray). Nutrient management by use of PROM, FYM and neem cake improved chemical, physical and biological properties of soil which lead to higher growth of roots which might have resulted in increased absorption and efficient translocation of nutrients towards plant system during vegetative growth. The above finding is in accordance with finding of Louduraj et al., (2005) in bhendi and Malarvizhi et al., (2009) in paprika cv. Kt-PI-19, Chetri et al., (2012) in capsicum, Baliah et al., (2015) and Eifediyi et al., (2015) in okra.

\section{Fruit length (cm)}

The data pertaining to effect of organic manures and liquid formulations upon fruit length clearly showed its significant effect. The fruit length was observed significantly highest i.e. $12.52 \mathrm{~cm}$ under $\mathrm{M}_{3}$ treatment (i.e. FYM $1 / 3^{\text {rd }}+$ PROM $1 / 3^{\text {rd }}+\mathrm{NC} 1 / 3^{\text {rd }}$ equivalent to $100 \% \mathrm{RDN}$ ) and $13.26 \mathrm{~cm}$ under in $\mathrm{L}_{1}$ treatment (i.e. panchagavya @ 3\% spray) while, the lowest fruit length i.e. $11.49 \mathrm{~cm}$ with treatment of $\mathrm{M}_{2}$ (i.e. FYM $1 / 3^{\text {rd }}+\mathrm{EC}$ $1 / 3^{\text {rd }}+\mathrm{VC} 1 / 3^{\text {rd }}$ equivalent to $100 \% \mathrm{RDN}$ ) and $10.41 \mathrm{~cm}$ with $\mathrm{L}_{6}$ treatment was observed.

The fruit length was observed significantly maximum i.e. $14.83 \mathrm{~cm}$ with $\mathrm{M}_{3} \mathrm{~L}_{1}$ treatment (i.e. FYM $1 / 3^{\text {rd }}+\operatorname{PROM} 1 / 3^{\text {rd }}+\mathrm{NC} 1 / 3^{\text {rd }}$ equivalent to $100 \%$ RDN and panchagavya @ $3 \%$ spray at flowering and after 15 DAF) while, minimum fruit length was recorded under $\mathrm{M}_{2} \mathrm{~L}_{6}$ treatment (i.e. FYM1/3 ${ }^{\mathrm{rd}}+\mathrm{EC} 1 / 3^{\text {rd }}$ $+\mathrm{VC} 1 / 3^{\text {rd }}$ equivalent to $100 \% \mathrm{RDN}$ and Water spray). 
Table.1 Effect of organic manures and liquid formulations on days to first picking, fruit length, fruit weight, yield per hectare and fiber content of okra

\begin{tabular}{|c|c|c|c|c|c|}
\hline Treatments & $\begin{array}{c}\text { Days to } \\
\text { first } \\
\text { picking }\end{array}$ & $\begin{array}{l}\text { Fruit } \\
\text { length } \\
(\mathrm{cm})\end{array}$ & $\begin{array}{c}\text { Fruit } \\
\text { Weight }(g)\end{array}$ & $\begin{array}{l}\text { Yield } \\
\text { (q/ha) }\end{array}$ & $\begin{array}{c}\text { Fiber } \\
\text { content }(\%)\end{array}$ \\
\hline \multicolumn{6}{|c|}{ Organic Manures (M) } \\
\hline $\begin{array}{c}\mathrm{M}_{1}\left(\mathrm{FYM} 1 / 3^{\mathrm{rd}}+\mathrm{VC} 1 / 3^{\mathrm{rd}}+\mathrm{NC} 1 / 3^{\mathrm{rd}}\right. \\
\text { equivalent to } 100 \% \mathrm{RDN})\end{array}$ & 48.60 & 11.87 & 9.49 & 92.63 & 1.71 \\
\hline $\begin{array}{c}\mathrm{M}_{2}\left(\mathrm{FYM} 1 / 3^{\text {rd }}+\mathrm{EC} 1 / 3^{\text {rd }}+\mathrm{VC} 1 / 3^{\text {rd }}\right. \\
\text { equivalent to } 100 \% \mathrm{RDN})\end{array}$ & 49.37 & 11.49 & 9.48 & 90.33 & 1.58 \\
\hline $\begin{array}{c}\mathrm{M}_{3}\left(\mathrm{FYM} 1 / 3^{\text {rd }}+\mathrm{PROM} 1 / 3^{\text {rd }}+\mathrm{NC} 1 / 3^{\text {rd }}\right. \\
\text { equivalent to } 100 \% \mathrm{RDN})\end{array}$ & 47.83 & 12.52 & 10.10 & 104.22 & 1.54 \\
\hline SEm \pm & 0.09 & 0.11 & 0.10 & 1.27 & 0.02 \\
\hline C.D.@ 5\% & 0.35 & 0.44 & 0.39 & 4.97 & 0.06 \\
\hline \multicolumn{6}{|c|}{ Liquid Formulations (L) } \\
\hline $\mathrm{L}_{1}($ Panchagavya spray 3\%) & 47.00 & 13.26 & 10.27 & 107.46 & 1.41 \\
\hline L L $_{2}$ Jeevamrut spray @ 500 lit/ha) & 47.98 & 12.44 & 9.69 & 96.34 & 1.56 \\
\hline $\mathrm{L}_{3}($ Cow urine spray $10 \%)$ & 49.00 & 11.62 & 9.53 & 93.24 & 1.53 \\
\hline $\mathrm{L}_{4}($ Vermiwash spray $10 \%)$ & 47.80 & 12.58 & 10.00 & 100.12 & 1.46 \\
\hline $\mathrm{L}_{5}$ (Matka khad spray $10 \%$ ) & 49.16 & 11.44 & 9.42 & 90.81 & 1.66 \\
\hline $\mathrm{L}_{6}$ Control (Water spray) & 50.67 & 10.41 & 9.22 & 86.39 & 2.04 \\
\hline SEm \pm & 0.24 & 0.10 & 0.15 & 1.89 & 0.02 \\
\hline C.D.@ 5\% & 0.70 & 0.28 & 0.43 & 5.46 & 0.04 \\
\hline \multicolumn{6}{|c|}{ Interaction (MxL) } \\
\hline $\mathbf{M}_{1} \mathbf{L}_{1}$ & 47.60 & 12.63 & 9.67 & 96.02 & 1.63 \\
\hline $\mathbf{M}_{1} \mathbf{L}_{2}$ & 48.00 & 12.37 & 9.47 & 93.33 & 1.63 \\
\hline $\mathbf{M}_{1} \mathbf{L}_{3}$ & 49.00 & 11.63 & 9.47 & 92.89 & 1.70 \\
\hline $\mathbf{M}_{1} \mathbf{L}_{4}$ & 47.80 & 12.50 & 9.67 & 95.42 & 1.50 \\
\hline $\mathbf{M}_{1} \mathbf{L}_{5}$ & 49.07 & 11.53 & 9.33 & 89.97 & 1.80 \\
\hline $\mathbf{M}_{1} \mathbf{L}_{6}$ & 50.13 & 10.53 & 9.33 & 88.16 & 1.97 \\
\hline $\mathbf{M}_{2} \mathbf{L}_{1}$ & 48.33 & 12.30 & 9.80 & 95.89 & 1.37 \\
\hline $\mathbf{M}_{2} \mathbf{L}_{2}$ & 48.60 & 12.13 & 9.40 & 90.95 & 1.43 \\
\hline $\mathbf{M}_{2} \mathbf{L}_{3}$ & 49.20 & 11.33 & 9.33 & 88.60 & 1.50 \\
\hline $\mathbf{M}_{2} \mathbf{L}_{4}$ & 48.47 & 12.20 & 9.60 & 94.29 & 1.67 \\
\hline $\mathbf{M}_{2} \mathbf{L}_{5}$ & 49.53 & 11.10 & 9.40 & 88.74 & 1.43 \\
\hline $\mathbf{M}_{2} \mathbf{L}_{6}$ & 52.07 & 9.87 & 9.33 & 83.49 & 2.07 \\
\hline $\mathbf{M}_{3} \mathbf{L}_{1}$ & 45.07 & 14.83 & 11.33 & 130.47 & 1.23 \\
\hline $\mathbf{M}_{3} \mathbf{L}_{2}$ & 47.33 & 12.83 & 10.20 & 104.73 & 1.60 \\
\hline $\mathbf{M}_{3} \mathbf{L}_{3}$ & 48.80 & 11.90 & 9.80 & 98.23 & 1.40 \\
\hline $\mathbf{M}_{3} \mathbf{L}_{4}$ & 47.13 & 13.03 & 10.73 & 110.67 & 1.20 \\
\hline $\mathbf{M}_{3} \mathbf{L}_{5}$ & 48.87 & 11.70 & 9.53 & 93.72 & 1.73 \\
\hline$M_{3} L_{6}$ & 49.80 & 10.83 & 9.00 & 87.53 & 2.10 \\
\hline SEm \pm & 0.41 & 0.17 & 0.25 & 3.27 & 0.03 \\
\hline C.D. @ 5\% & 1.21 & 0.49 & 0.75 & 9.46 & 0.08 \\
\hline
\end{tabular}


It would be relevant to recall here that increased nitrogen fixation by FYM and neem cake has ability of nitrification inhibitor thereby increased nitrogen availability in plant. Plants can take up the required nutrient according their demand resulting in improved growth and development.

\section{Fruit weight (g)}

The fruit weight $(\mathrm{g})$ was obtained significantly maximum i.e. $10.10 \mathrm{~g}$ with $\mathrm{M}_{3}$ treatment (i.e. FYM $1 / 3^{\text {rd }}+$ PROM $1 / 3^{\text {rd }}+\mathrm{NC} 1 / 3^{\text {rd }}$ equivalent to $100 \% \mathrm{RDN}$ ) while, the minimum fruit weight i.e. $9.48 \mathrm{~g}$ was found with treatment of $\mathrm{M}_{2}$ (i.e. FYM $1 / 3^{\text {rd }}+\mathrm{EC}$ $1 / 3^{\text {rd }}+\mathrm{VC} 1 / 3^{\text {rd }}$ equivalent to $\left.100 \% \mathrm{RDN}\right)$. The highest fruit weight i.e. $10.27 \mathrm{~g}$ was recorded with $\mathrm{L}_{1}$ treatment (i.e. panchagavya @ 3\% spray) which was at par with treatment of $\mathrm{L}_{4}$ (vermiwash spray 10\%) while, the lowest fruit weight $(\mathrm{g})$ i.e. $9.22 \mathrm{~g}$ was found with $\mathrm{L}_{6}$ treatment (water spray). The $\mathrm{M}_{3} \mathrm{~L}_{1}$ treatment (i.e. FYM $1 / 3^{\text {rd }}+$ PROM $1 / 3^{\text {rd }}+\mathrm{NC}$ $1 / 3^{\text {rd }}$ equivalent to $100 \% \quad \mathrm{RDN}$ and panchagavya @ 3\% spray) was recorded significantly maximum fruit weight i.e. 11.33 $\mathrm{g}$ which was found at par with $\mathrm{M}_{3} \mathrm{~L}_{4}$ treatment while, treatment of $\mathrm{M}_{3} \mathrm{~L}_{6}$ (i.e. $\mathrm{FYM} 1 / 3^{\text {rd }}+$ PROM $1 / 3^{\text {rd }}+\mathrm{NC} 1 / 3^{\text {rd }}$ equivalent to $100 \%$ RDN and Water spray) was observed minimum fruit weight i.e. $9.00 \mathrm{~g}$. Panchagavya contains macronutrients such as $\mathrm{N}, \mathrm{P}, \mathrm{K}$ and micronutrients needed for various vitamins, amino acids, growth regulators such as auxins and gibberellins which are required for proper growth and development of plants. Similar results were recorded by Malarvizhi et al., (2009) in paprika cv. Kt-PI-19 and Swain et al., (2015) in chilli.

\section{Yield per hectare (q / ha)}

The highest yield per hectare i.e.104.22 q was reported under $\mathrm{M}_{3}$ treatment (i.e. FYM $1 / 3^{\text {rd }}+$ PROM $1 / 3^{\text {rd }}+\mathrm{NC} 1 / 3^{\text {rd }}$ equivalent to $100 \%$
RDN) and $107.46 \mathrm{q}$ was recorded with $\mathrm{L}_{1}$ treatment (i.e. panchagavya @ 3\% spray) whereas, the lowest yield per hectare i.e. 90.33 $\mathrm{q}$ with $\mathrm{M}_{2}$ treatment (i.e. FYM $1 / 3^{\text {rd }}+\mathrm{EC} 1 / 3^{\text {rd }}$ $+\mathrm{VC} 1 / 3^{\text {rd }}$ equivalent to $100 \% \mathrm{RDN}$ ) and $86.39 \mathrm{q}$ with $\mathrm{L}_{6}$ treatment were obtained. The yield per hectare was observed significantly highest (i.e. 130.47 q) with $\mathrm{M}_{3} \mathrm{~L}_{1}$ treatment i.e. $\mathrm{FYM} 1 / 3^{\text {rd }}+$ PROM $1 / 3^{\text {rd }}+\mathrm{NC} 1 / 3^{\text {rd }}$ equivalent to $100 \%$ RDN and panchagavya @ $3 \%$ spray) while, the lowest yield per hectare (i.e. 83.49 q) was recorded under $\mathrm{M}_{2} \mathrm{~L}_{6}$ treatment (i.e. FYM $1 / 3^{\text {rd }}+\mathrm{EC} 1 / 3^{\text {rd }}+\mathrm{VC}$ $1 / 3^{\text {rd }}$ equivalent to $100 \% \mathrm{RDN}$ and Water spray). A significant effect of PROM and FYM for augmented yield might be the enhanced establishment of micro-organism population in rhizosphere as the organic matter in addition providing physical properties also insured nutrient availability and food supply for plants. Phosphorus is essential for protein synthesis, chlorophyll and for establishment of good root mass. Similar results were noted through using organic manures by Eifediyi et al., (2015), Khandaker et al., (2017) and Miglani et al., (2017) in okra.

\section{Fiber content (\%)}

The fiber content was observed significantly minimum i.e. $1.54 \%$ with $\mathrm{M}_{3}$ treatment (i.e. FYM $1 / 3^{\text {rd }}+$ PROM $1 / 3^{\text {rd }}+\mathrm{NC} 1 / 3^{\text {rd }}$ equivalent to $100 \% \mathrm{RDN}$ ) and $1.41 \%$ with $\mathrm{L}_{1}$ treatment (i.e. panchagavya @ 3\% spray) while, the maximum fiber content i.e. $1.71 \%$ was found with treatment of $\mathrm{M}_{1}$ (i.e. $\mathrm{FYM}$ $1 / 3^{\text {rd }}+\mathrm{VC} 1 / 3^{\text {rd }}+\mathrm{NC} 1 / 3^{\text {rd }}$ equivalent to $100 \%$ $\mathrm{RDN}$ ) and $2.04 \%$ was found with $\mathrm{L}_{6}$ treatment (water spray). The fiber content was observed significantly lowest i.e. $1.20 \%$ under $\mathrm{M}_{3} \mathrm{~L}_{4}$ treatment (i.e. FYM $1 / 3^{\text {rd }}+$ PROM $1 / 3^{\text {rd }}+\mathrm{NC}$ $1 / 3^{\text {rd }}$ equivalent to $100 \% \mathrm{RDN}$ and vermiwash spray $10 \%$ ) whereas, the highest fiber content $2.07 \%$ was obtained with $\mathrm{M}_{3} \mathrm{~L}_{6}$ treatment (i.e. FYM $1 / 3^{\text {rd }}+$ PROM $1 / 3^{\text {rd }}+\mathrm{NC} 1 / 3^{\text {rd }}$ 
equivalent to $100 \%$ RDN with Water spray). Application of organic form of nitrogen reduced the fiber content. This is due to easy availability of nitrogen and organic carbon lead to balanced $\mathrm{C}: \mathrm{N}$ ratio which improved the quality of produce. Similar response was recorded by Premsekhar and Rajshree (2009) and Alam et al., (2019) in okra.

The application of $\mathrm{M}_{3} \mathrm{~L}_{1}$ treatment (i.e. FYM 1/3rd + PROM 1/3rd + neem cake (NC) 1/3rd equivalent to $100 \%$ RDN along with foliar spray of panchagavya@ $3 \%$ at flowering and 15 days after flowering) improved and increased the different characteristics of growth of okra.

\section{References}

Alam, S. M., Ullah, M. A., Haider, S. I., Nawab, N. N., Aamir, S. S. and Mahmood, I. A., 2019. Effect of farm yard manure and planting densities on growth, yield and quality of okra under natural farming. International Journal of Research in Agriculture and Forestry, 6: 21-25.

Baliah, N. T., Priyatharsini, S. L. and Priya, C., 2015. Effect of organic fertilizers on the growth and biochemical characteristics of okra (Abelmoschus esculentus (L.) Moench]. International Journal of Science and Research, 3: 1272-1280.

Bose, T. K., Kabir, J., Maity, T. K., Parthasarathy, V. A. and Som, M. G., 2003. Vegetables Crops Volume-3. Naya Prokash, Calcutta (India). pp. 209-240.

Chetri, D. A., Singh, A. K. and Singh, V. B., 2012. Effect of integrated nutrient management on yield, quality and nutrient uptake by capsicum (Capsicum annum) cv. California wonder. Soils and Crops, 21: 44-48.

Eifediyi, E. K., Mohammed, K. O. and
Remison, S. U., 2015. Effects of neem (Azadirachta indica L.) Seed cake on the growth and yield of okra (Abelmoschus esculentus (L.) Moench). Poljoprivreda, 21: 46-52.

Khandaker, M. M., Jusoh, N., Ralmi, N. H. A. A., and Ismail, S. Z., 2017. The effect of different types of organic fertilizers on growth and yield of Abelmoschus esculentus L. Moench (okra). Bulgarian Journal of Agricultural Science, 23: 119-125.

Louduraj, C. A., Bhoomi, R. K. and Paneer, S. S., 2005. Yield attributes and grain yield of rice as influenced by organic farming and organic manure on the production on bhendi, Proc. Sem. Organic Agriculture Peninsular India, pp. 187-188 and 159-163.

Malarvizhi, K., Ponnuswami, V., Kavino, M. and Selvi, B. S., 2009. Effect of growth promoters on growth and yield of paprika cv. Kt-P1-19. Crops Research, 37: 144-147.

Maynard, A. J., 1970. Methods in food analysis academies press New York, pp. 176.

Miglani, A., Ghandhi, N., Singh, N. and Kaur, J., 2017. Influence of different organic manures on growth and yield of okra. International Journal of Advance Research in Science and Engineering, 6: 886-892.

Pathak, R. K. and Ram, R. A., 2013. Bioenhancers: A potential tool to improve soil fertility, plant health in organic production of horticulture crops. Progressive Horticulture, 45(2):237254.

Pradhan, S. S., Verma, S., Kumari, S. and Singh, Y. 2018. Bio-efficacy of cow urine on crop production: A review. International Journal of Chemical Studies, 6: 298-301.

Premsekhar, M. and Rajshree, V., 2009. Influence of organic manures on 
growth, yield and quality of okra. American-Eurasian Journal of Sustainable Agriculture, 3: 6-8.

Sharma, I. J., Samnotra, R. K., Kumar, V., Rai, A. P. and Dhotra, B., 2015. Effect of organic and inorganic fertilizers on the growth and yield of okra under sub-tropical region. Annals of Plant and Soil Research, 17: 215-218.

Shivasubramanian, K. and Ganeshkumar, M., 2004. Influence of vermiwash on biological productivity of marigold. Madras Agriculture Journal, 91: 221225.
Swain, S. S., Sahu, G. S. and Mishra, N., 2015. Effect of panchagavya on growth and yield of chilli (L.) cv. Kuchinda Local. Green Farming, 2: 338-340.

Tadesse, T., Dechassa, N., Bayu, W., and Gebeyehu, S., 2013. Effects of farmyard manure and inorganic fertilizer application on soil physicochemical properties and nutrient balance in rain-fed lowland rice ecosystem. American Journal of Plant Sciences, 4: 309-316.

\section{How to cite this article:}

Priyanka Devanda, S. S. Lakhawat, S. Pilania, S. K. Sharma, Azad Mordia, D. P. S. Dudi, Sharvan Kumar Yadav and Pratishtha Diwaker. 2021. Effect of Organic Manures and Liquid Formulations on Growth, Yield and Quality of Okra [Abelmoschus esculentus (L.) Moench] cv. Arka Anamika. Int.J.Curr.Microbiol.App.Sci. 10(06): 426-433. doi: https://doi.org/10.20546/ijcmas.2021.1006.045 